\title{
Congenital malformations: from superstition to understanding
}

\author{
J. Bruce Beckwith
}

Received: 29 September 2012 / Accepted: 11 October 2012 /Published online: 26 October 2012

(C) Springer-Verlag Berlin Heidelberg 2012

Throughout most of human history, congenital anomalies were perceived as omens, portents, or punishments of supernatural origin. This concept is reflected in the term "monster," probably derived from the Latin verb monstrare (to show or reveal). Other explanations for congenital abnormalities included witchcraft, astrological configurations, or emotional experiences of the pregnant mother. Malformed humans and animals also inspired many of the characters populating the literature, mythology, art, and religion of every culture.

By the eighteenth century superstition still dominated public conceptions of malformations, but this topic was beginning to attract serious attention from physicians and scientists. Abnormalities such as conjoined twins were a popular subject for anatomists, who produced some superb morphological studies. However, scientific investigation of causes and mechanisms of abnormal development were delayed because of persisting support for the concept of preformation of embryos. Toward the end of the century, epigenesis finally achieved acceptance by leading scientists, opening the door to the investigation of normal and abnormal development.

By the dawn of the nineteenth century, a foundation had been established for the study of abnormal development, which was destined to become one of the most productive of biomedical sciences. The ultimate mechanisms of normal and abnormal development are now explored at the molecular level, and the lives of countless individuals born with malformations have been greatly enhanced by advances in medicine and surgery. No other biomedical science provides a more colorful and instructive illustration of the long

\section{J. B. Beckwith $(\square)$}

Department of Pathology and Human Anatomy,

Loma Linda University,

Loma Linda, CA, USA

e-mail: beckwithbrowning@earthlink.net journey from superstition to understanding. The older literature in this field, in addition to its historical interest, is a source of knowledge and information of unique value for scientists and practitioners.

\section{Ancient and primitive cultures}

Accurate depictions of malformations that are clearly based upon actual cases are included in the art, folklore, and literature of many cultures (Fig. 1). Other figures, such as mermaids, cyclops, chimeras, and multiheaded and janiform monsters, though possibly inspired by cases of malformation, are embellished or distorted in their description and artistic representation. While most anomalous cases engendered negative reactions, some were esteemed as divinities or shamans. Achondroplasia and other forms of dwarfism are portrayed as divinities in the art of ancient Egypt and Greece [1] as well as pre-Hispanic cultures of Central and South America (Fig. 2).

Birth defects were interpreted as omens or portents in many early cultures. For example, Babylonian-Assyrian cuneiform tablets include an extensive catalog of anomalies believed to represent omens, some of which are clearly based upon observation of actual cases. For example, "If a woman gives birth and the anus is closed, the land will suffer famine" [2].

\section{0-1650: the age of prodigy books}

The sixteenth century was described by Jean Céard [3] as "the golden age of prodigy books," reflecting the popularity of illustrated books, manuscripts, and broadsides depicting malformed humans and animals as omens or portents of profound supernatural significance. The quintessential prodigy book 


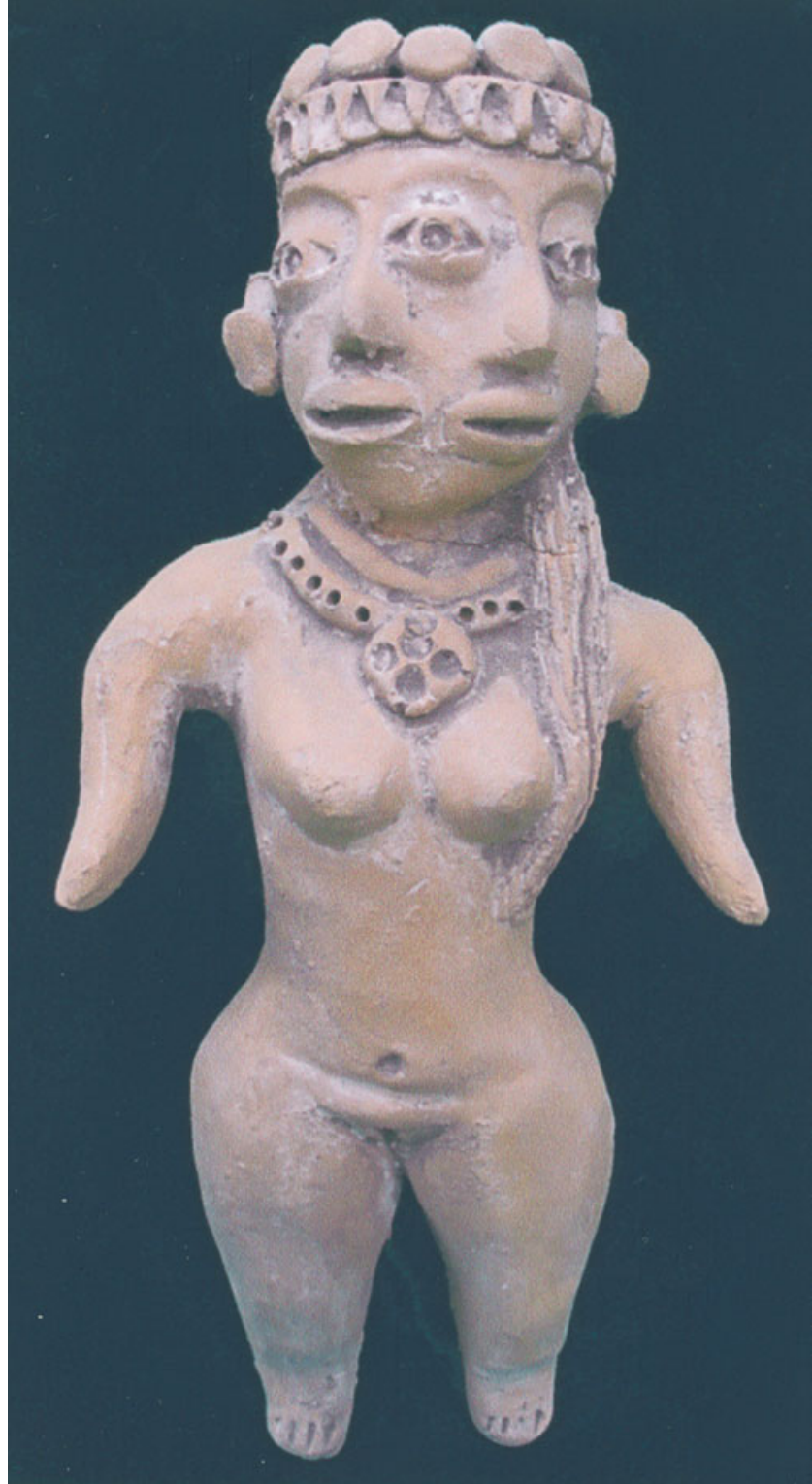

Fig. 1 Diprosopus triophthalmos precolumbian figurine from Mexico. Author's collection; reproduction of an original in the museum of anthropology in Mexico City, a generous gift from Dr. P.V. Mayoral, pathologist at the Children's Hospital in that city

was the 1557 chronicle of Conrad Lycosthenes (1518-1565) [4]. This thick folio, embellished by some 1,500 woodcut illustrations, is a compendium of unusual natural phenomena both real and alleged, spanning the history of the world from the temptation of Eve to the year of publication. Particular emphasis was upon the temporal association of anomalous births of humans or animals with significant historical events. Though most "monsters" described in this work are either fictional or imaginatively embellished, it also includes some reasonably accurate depictions of conjoined twins, limb anomalies, and other malformations. A reprint of the 1557 German edition makes this fascinating work accessible to modern readers.

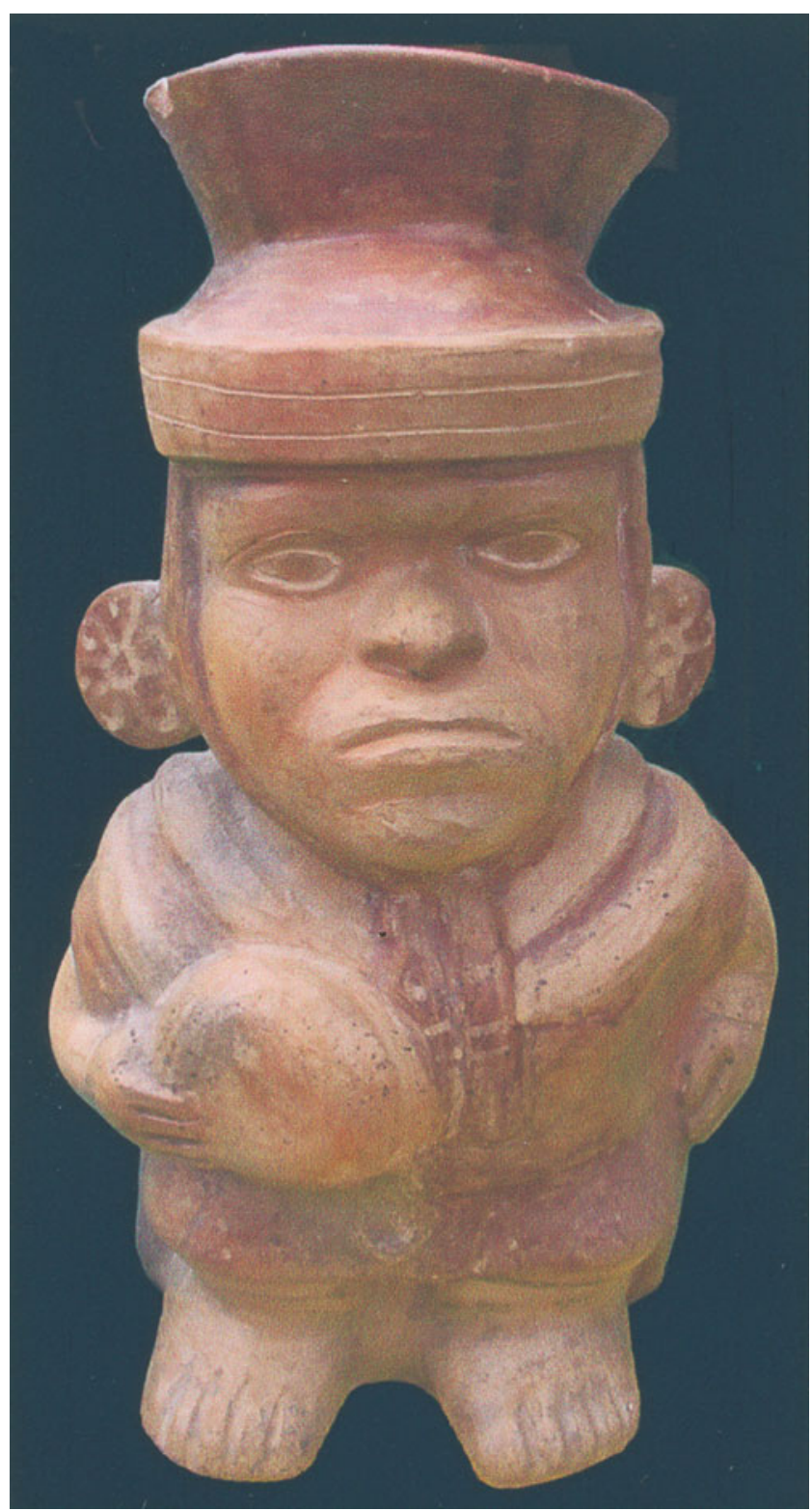

Fig. 2 Achondroplasia. Moche figural vessel, ca. 200-300 C.E. 32-cm tall. Author's collection

Somewhat less credulous than the work of Lycosthenes was the 1573 treatise on monsters and prodigies by the great pioneer of French surgery, Ambroise Paré (1510-1590) [5]. Accurately depicted anomalies observed by Paré and other contemporary observers are presented, but these were not distinguished from fictional or imaginatively embellished abnormalities. This work is readily available to modern readers in reprinted versions, including the fine scholarly French edition of Céard [6] and the English translation by Pallister [7]. The 1554 treatise by Jakob Rueff (1500-1558), intended for midwives [8], includes a chapter on teratological cases. Brief descriptions and simple woodcuts accurately depicting conjoined twins, limb reduction defects, and 
other anomalies are presented along with fictitious cases copied from other sources.

Several notable works devoted to malformations appeared during the first half of the seventeenth century. Most notable of these was the posthumously published Monstrorum Historia of Ulysses Aldrovandi (1522-1605) [9]. This elegant folio volume features 366 attractive woodcut illustrations, many full pages depicting a wide variety of malformations in humans and plant and animal species. Excellent depictions of actual specimens are included along with substantial numbers of apocryphal ones. An emerging scientific approach to this subject is reflected in the organization of the book according to pattern or site of abnormality, such as rostral duplications and dwarfism. The 1634 and subsequent editions of the treatise of Fortunio Liceti (15771657) [10] are notable for their attractive copper engravings. This work was primarily concerned with the presumed significance of anomalies rather than their accurate depiction, with numerous impossible or inaccurate representations such as human-quadruped chimeras. However, it contains a few accurately depicted cases, including an apparent example of trisomy 13 (Fig. 3). The 1609 monograph of Johann Georg Schenck [11] (d. 1620) features some excellent depictions of malformations in humans and animals (Fig. 4) in addition to numerous inaccurate or fanciful ones typical of works from this era.

Some of the earliest recorded postmortem examinations involved cases of malformation. The 1507 treatise on postmortem examinations of Antonio Benevieni (1443-1502) includes several cases of malformed infants [12]. The first reported necropsy in the western hemisphere was performed in 1533 on conjoined twins who died shortly after delivery. The examination was requested by clergy in order to determine if the twins had one soul or two [13].

\section{Mid-seventeenth to early eighteenth century: transition toward a science}

This period begins with a shining moment in the history of teratology. On page 233 of his pioneering 1651 treatise on embryology [14], William Harvey, after describing the upper lip of human fetuses as completing its formation from separate elements, suggested that failure of this process was the likely mechanism of development for congenitally cleft lip. Harvey's recognition that the study of embryology could provide the keys to understanding the causes and mechanisms of abnormal development was over a century ahead of his time. General acceptance of this view was delayed by strong support for the concept of preformation of embryos, defended by Haller, Buffon and other influential authorities of the eighteenth century. The works of Roe [15] and Tort [16] describe the vigorous intellectual debates during the latter part of that century that culminated in general acceptance of epigenesis as the mechanism of normal and abnormal development.

Though superstition and religion still dominated the subject of birth defects, early steps toward scientific teratology

Fig. 3 Figure on page 133 of Liceti's 1634 treatise on monsters [10]. Infant born in Fermo, Italy in 1624. Drawing by an unnamed artist who observed the infant both before and after death. The combination of cyclopia with a midline scalp defect is suggestive of trisomy 13

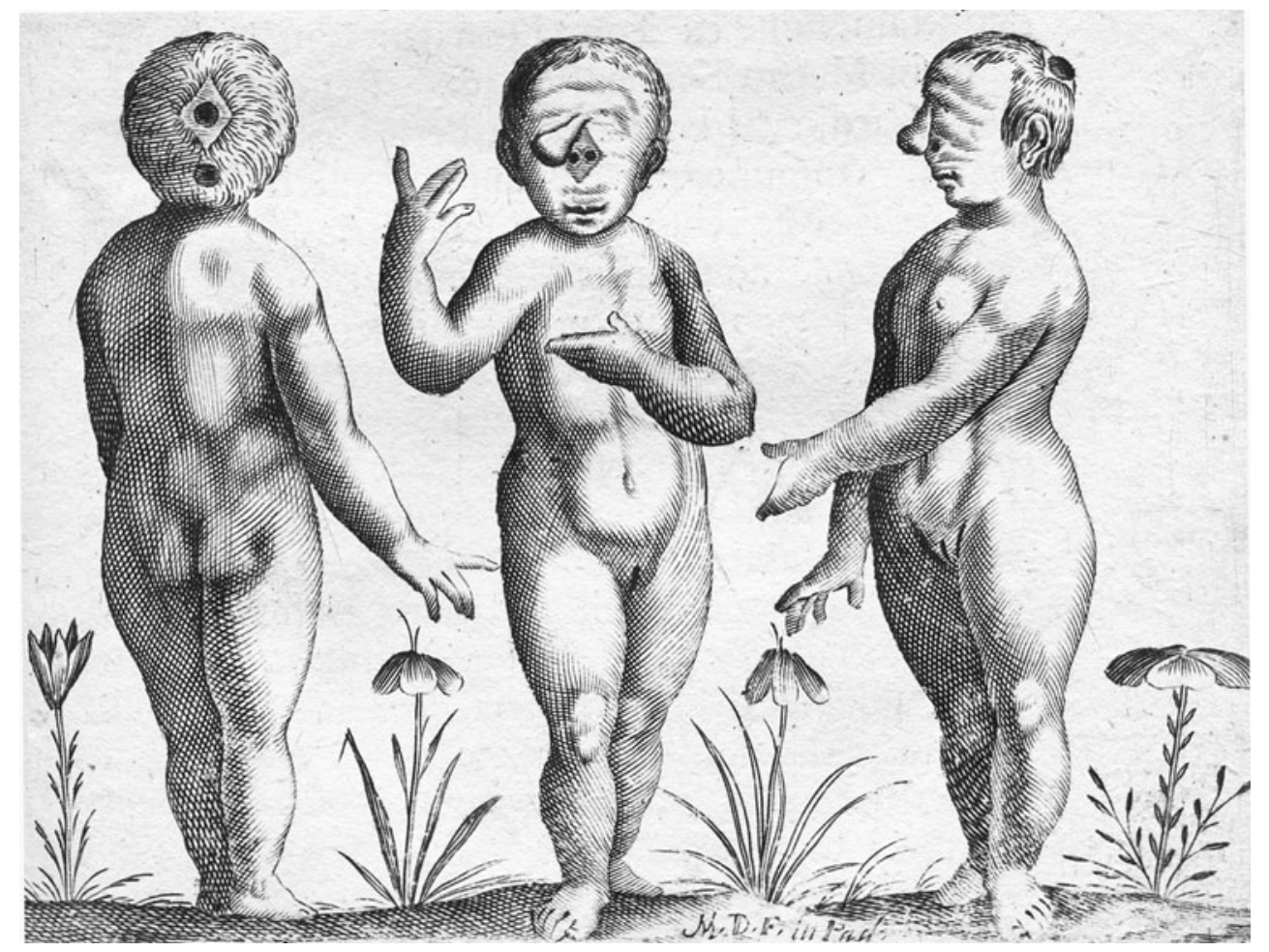


Fig. 4 Accurately depicted examples of limb anomalies from Schenck's 1609 treatise [11]

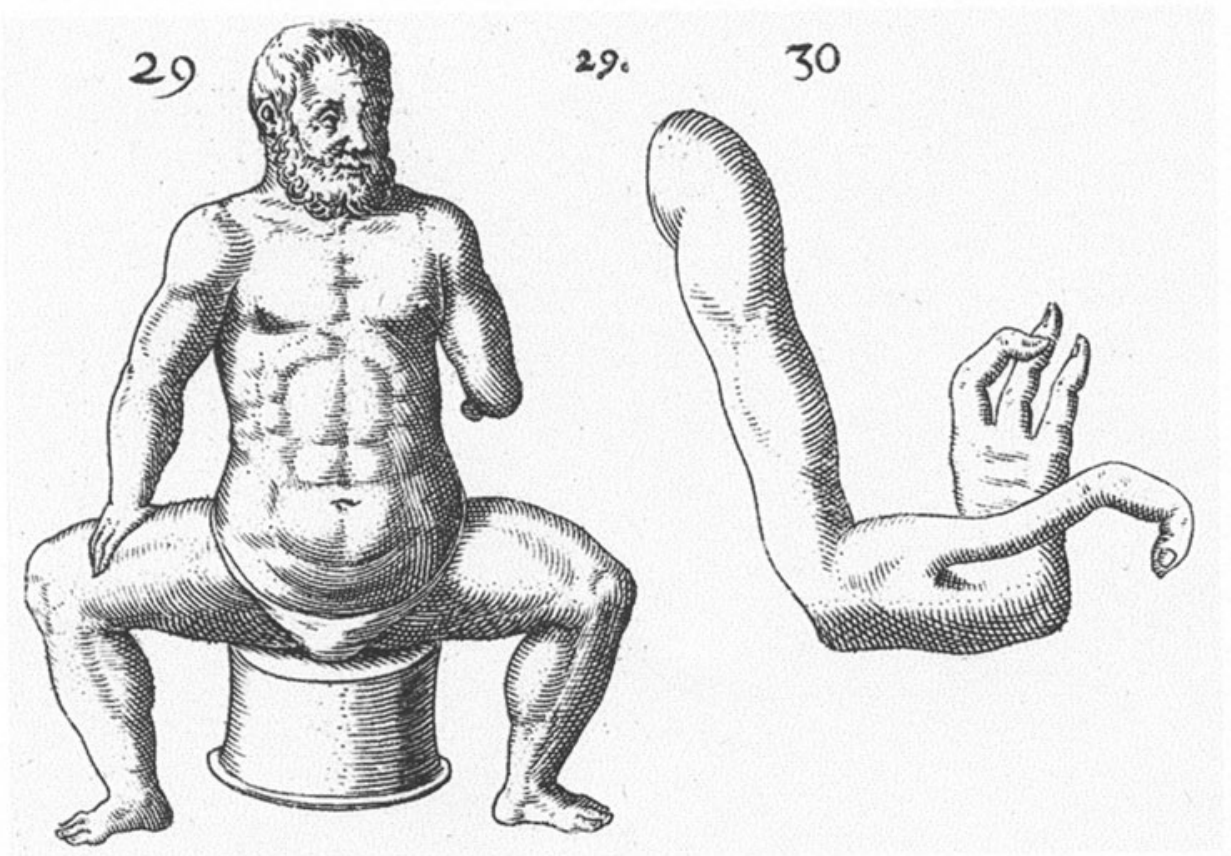

were manifested by an increasing proportion of accurately described cases and greatly improved quality of published descriptions and illustrations.

\section{Mid-eighteenth to early nineteenth centuries: the golden age of gross teratology}

During the second half of the eighteenth century, the study of the gross anatomy of malformation entered a new golden age, one that would continue through the early decades of the nineteenth century. During that period, when gross anatomy was the leading medical science, morphological studies of malformation attained levels of excellence rarely seen today. Advances in anatomical techniques and in medical and scientific illustration produced a rich heritage of magnificently illustrated works, many of which have never been surpassed. Numerous splendid monographs described specific patterns of malformation, such as that published in 1791 by Samuel Thomas Sömmerring (1755-1830) [17], featuring 12 engraved copperplates, six of which depicted a series of rostral duplications progressing from midline facial cleft through various degrees of diprosopus to dicephalus, a pioneering demonstration that patterns of malformation could be arranged and classified in a meaningful manner.

Albrecht von Haller (1708-1777), a dominant figure in scientific medicine for much of this century, has been credited by some authors as the founder of scientific teratology. The third volume of his Opera Minora, published in

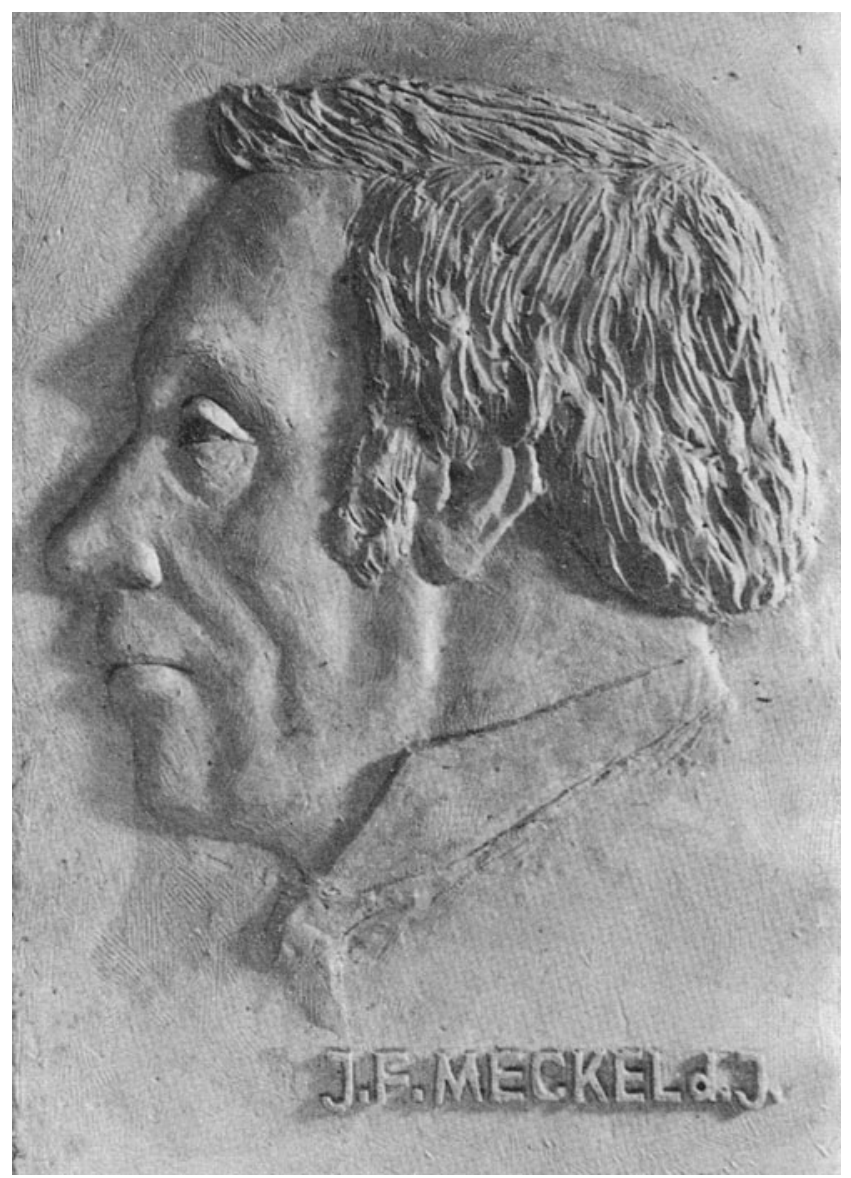

Fig. 5 J. F. Meckel the Younger. Soft tissue reconstruction of Meckel's facial features, based in part on remnants of his skull exhumed in 1967. From Schierhorn [26] 
1768 [18], largely devoted to the topic of malformations, has been described by some historians as the beginning of scientific teratology. Haller's emphasis upon accurate descriptions and depictions of cases and his influential role in the eradication of fanciful and inaccurate descriptions from the literature of science were influential in preparing the way for scientific teratology. However, his strong support of preformation during the latter decades of his life contributed to the delay in linking the topic of malformation to embryology. Vigorous debates during the eighteenth century, as mentioned above, stimulated scientific interest in the genesis of malformations and led to the general acceptance of the concept of epigenesis by the end of the century.

\section{Nineteenth and early twentieth century: teratology becomes a science}

This century witnessed the emergence of teratology as a recognized scientific discipline inextricably linked to the study of embryonic development. Much of the credit for establishing the union of teratology and embryology belongs to Johann Friedrich Meckel the younger (1781-1833, the last and greatest of the dynastic trio of great Meckel anatomists)
[19-21] (Fig. 5). The remarkable intelligence and technical skill of the Meckel triumvirate was unfortunately combined with significant emotional instability in their adult years [22]. While the younger Meckel was apparently a likeable and popular person in his early years, his forceful and arrogant personality led to difficult relationships with many colleagues in later life [23].

Meckel's early interest in the problem of malformation was reflected in his 1802 graduation dissertation devoted to congenital cardiac malformations and his pioneering 1809 study of the developmental significance of the ileal diverticulum bearing his name [24]. But his most important contribution was the epoch-making Handbuch der pathologischen Anatomie, published in two volumes from 1812 to 1818 [25]. This work is now generally credited as the beginning of scientific teratology $[19,26]$. Though not reflected in its title, volume 1 and the first 221 pages of volume 2 were devoted entirely to malformations. This was the first work to present a systematic approach to the entire spectrum of human anomalies, but its most important contribution was its emphasis upon the embryological mechanisms of abnormal development. Meckel recognized that malformations represented deviations from normal development and that extensive study of normal embryology must precede a true understanding of birth defects. He clearly

Fig. 6 Dicephalus tribrachius conjoined twins. Portion of plate 1 in Meckel's monograph on conjoined twins [27]. This figure exemplifies the excellence of anatomical dissection and illustration in many older publications

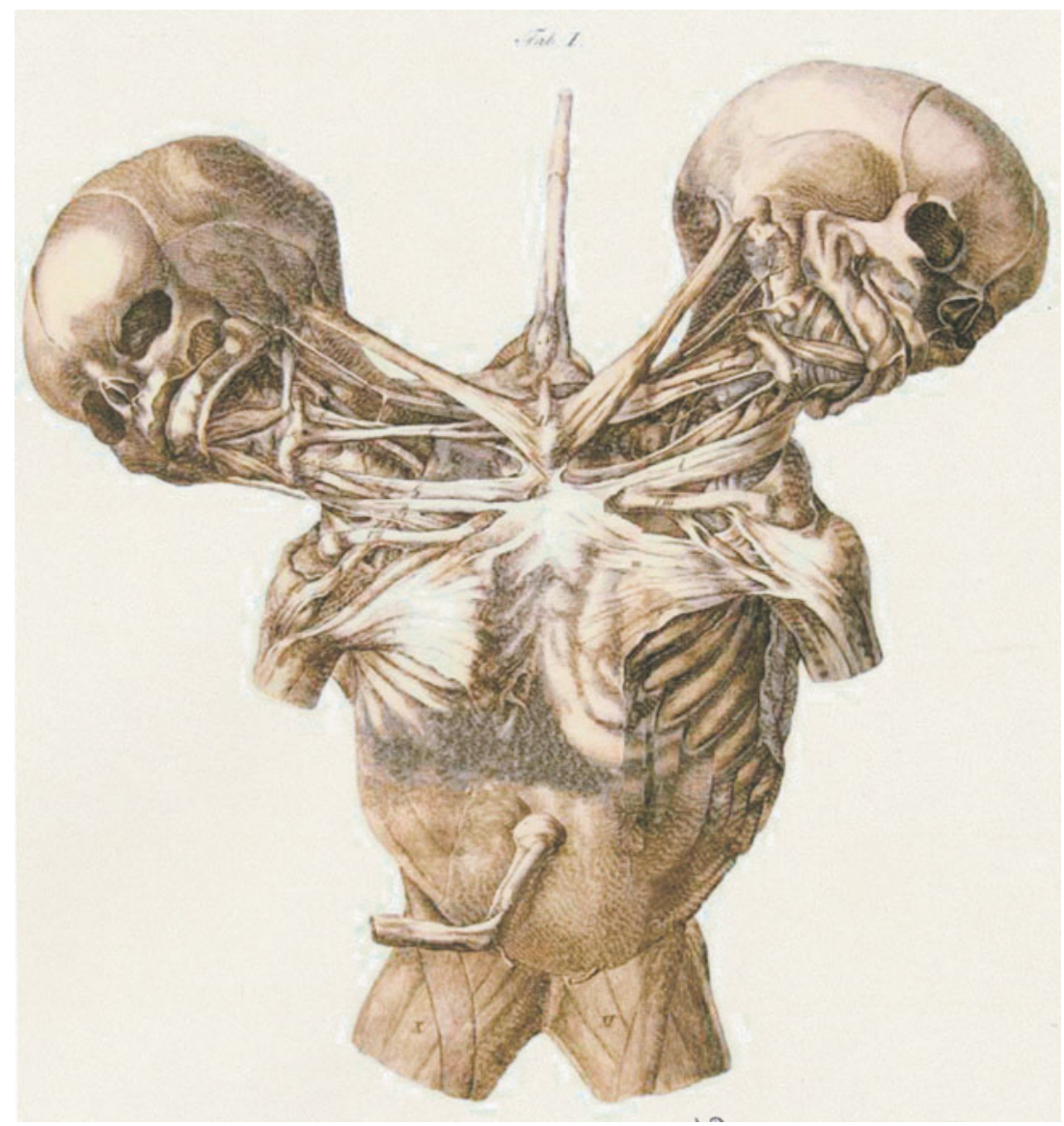




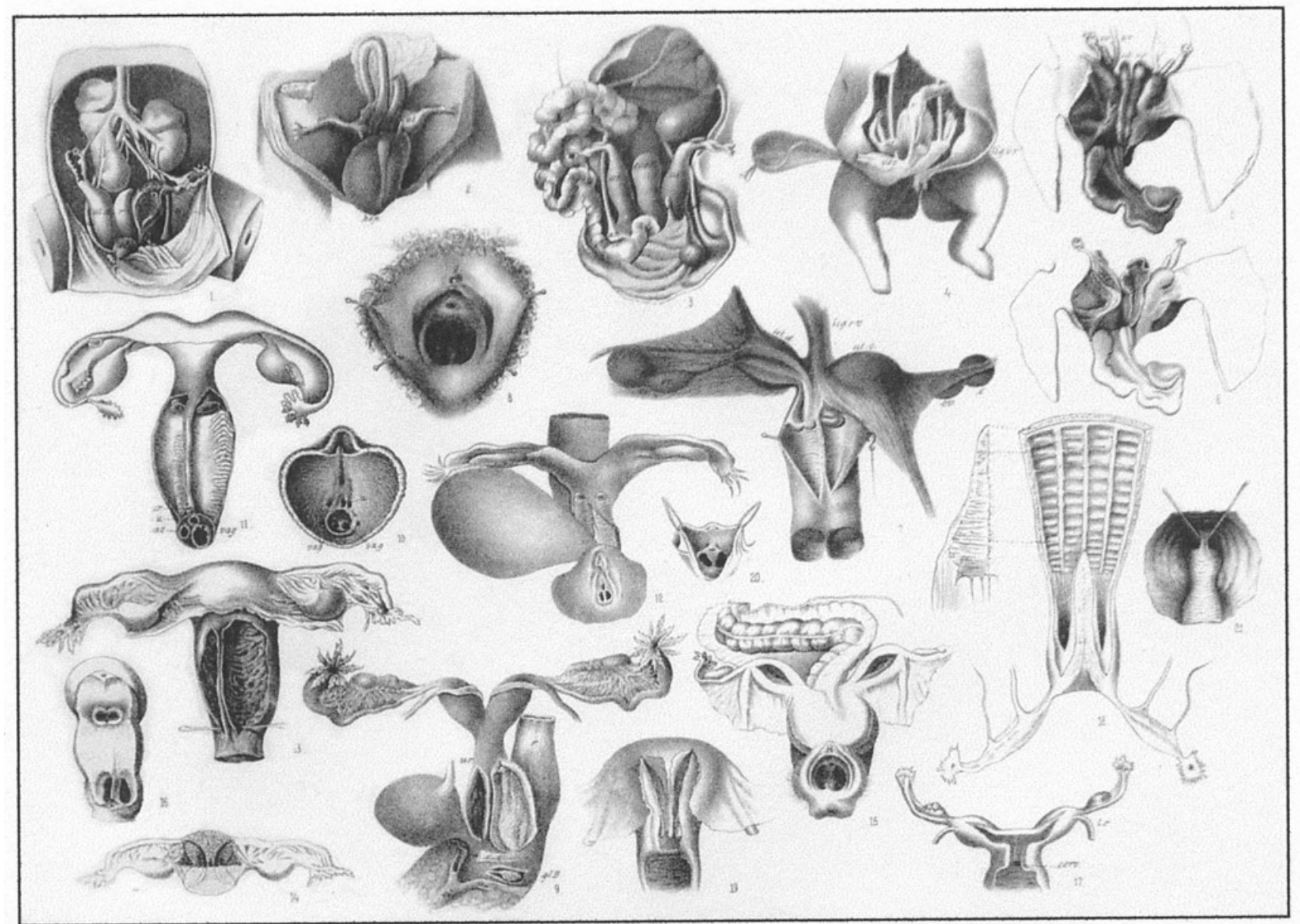

Fig. 7 Anomalies of the genital and urinary tracts. Plate 41 in Ahlfeld's superb atlas of malformations [39]

recognized the importance of developmental arrest, though placing excessive emphasis upon deficient or excessive formative energy (Bildungskraft) as the most important factor leading to structural defects. The concept of developmental arrest had been suggested by William Harvey in 1651, but not until Meckel's work did the study of malformations become inseparably linked to embryology.

In his remaining two decades, Meckel published numerous major contributions to the study of malformations. Most notable of these were his 1815 monograph on conjoined twinning [27] (Fig. 6), his splendidly illustrated atlas of pathological anatomy of several organ systems [28], and many contributions to journals, mostly in Deutsches Archiv für die Physiologie (1815-1823) and Archiv für Anatomie und Physiologie (1826-1832), both of which he edited. Klunker's valuable study of Meckel's scientific work, describing extant specimens from his teratological museum with color illustrations of many specimens, is available online [29].

Two other epochal contributions to this field followed in the 1830s. The best known and most influential of these was the treatise of Isidore Geoffroy Saint-Hilaire (1805-1861), referred to in this paper as "Geoffroy." His work consisted of three text volumes and an atlas published from 1832 to 1837 [30]. Isidore's father, Étienne (1772-1844), was a prominent and controversial figure in the history of French biology during the early decades of the nineteenth century [31], whose vigorous pursuit of unifying principles governing anatomical structure and development led to a monograph on malformations as clues to these general laws [32]. Isidore's treatise, probably stimulated by his father and written during the early years of his career, provided a comprehensive survey of the entire spectrum of malformations that emphasized anatomy, nomenclature, and classification more than pathogenesis. It introduced the term "teratology" for the scientific study of congenital anomalies and proposed numerous new terms for specific abnormalities, many of which have been perpetuated. This work proved immensely popular and played a major role in fostering scientific interest in the field of malformations. After completing this work, Isidore devoted his efforts to comparative anatomy, with only minor contributions to the literature of teratology.

A work comparable in excellence to that of Geoffroy was the 1832 treatise on malformations of domestic and 
agricultural animals by Ernst Friedrich Gurlt (1794-1882) [33]. Comprising part 2 of a treatise devoted to the pathological anatomy of species of interest to veterinarians, the text was accompanied by 25 lithographed plates featuring 136 finely executed figures illustrating a wide spectrum of malformations. This work remains one of the best descriptive works on mammalian teratology today. It was the first treatise to apply the Linnean binomial system of taxonomy to the entire spectrum of malformations. Geoffroy adopted this approach to classification of malformations in the second volume of his treatise, published in 1836. Gurlt published another superb treatise on veterinary teratology near the end of his long career [34]. This work features 20 finely lithographed plates with 119 figures, most of which depict the internal anatomy of malformations, adding to its value as a companion to the 1832 atlas, which was mostly devoted to external malformations.

The above foundation works were followed by a vast literature on descriptive and experimental teratology during the remainder of the nineteenth century, including many textbooks, monographs, dissertations, and atlases that remain invaluable resources for modern science and medicine. Works dealing with individual malformation categories are too numerous to mention here. Two examples of the many unique cases of permanent value to science include Fattori's depiction of a fetus containing two internal parasitic twins, one in the abdominal cavity and the other in the pelvis [35] (Fig. 7), and that of Baart de la Faille [36] concerning a fetus with twin parasitic fetuses attached to its palatal region (Figs. 8 and 9).

The next few paragraphs describe important general texts and atlases that feature numerous illustrations and descriptions of important cases of malformation. These collective works are invaluable for those seeking rare or instructive cases from the older literature. Though most are in languages other than English, the fine illustrations make them worthwhile even for those unable to appreciate the accompanying text. Most are relatively rare, but some are available in reprint form, as indicated in the reference list, and many others are being added to readily accessible digital archives. Regrettably, the folded plates, the crowning feature of most works in this field, have been scanned in the folded state in most currently available digital volumes, and colored plates are often reproduced in black and white.

The splendid atlas by Willem Vrolik (1801-1862) [37], the illustrated companion to his two-volume textbook of teratology [38], consists of 101 beautifully lithographed plates, with accompanying text in both Latin and Dutch. Covering a wide spectrum of anomalies from the literature as well as specimens in the Vrolik Museum at the University of Amsterdam, this work is an invaluable resource of permanent value. Vrolik's textbook deserves a place of honor in the literature of teratology, though its influence was limited by its having been published only in Dutch.
The text and large folio atlas of Friedrich Ahlfeld (18431929) [39], though less well known than that of Vrolik, is one of the great treasures of teratology. Its 49 plates with 750 finely lithographed figures, printed on heavy stock, make it an invaluable resource (Fig. 7). The illustrations depict instructive, unique, or important cases selected from the literature, unpublished museum specimens, or cases studied by Ahlfeld. External, skeletal, and visceral anomalies are included. The text volumes indicate the source of each figure and discuss its salient features. This work does not include all patterns of human malformation but includes excellent coverage of conjoined twinning and other duplication anomalies, clefts of various body parts, urogenital abnormalities, cyclopia, microcephaly, and various other anomalies. Ahlfeld, a prominent German obstetrician with a deep interest in teratology, possessed a superb library of teratological works, the nineteenth century portion of which has been maintained intact in the Welch Library of the Johns Hopkins University School of Medicine.

Friedrich August von Ammon (1799-1861) published in 1842 a splendid atlas of malformations that are of

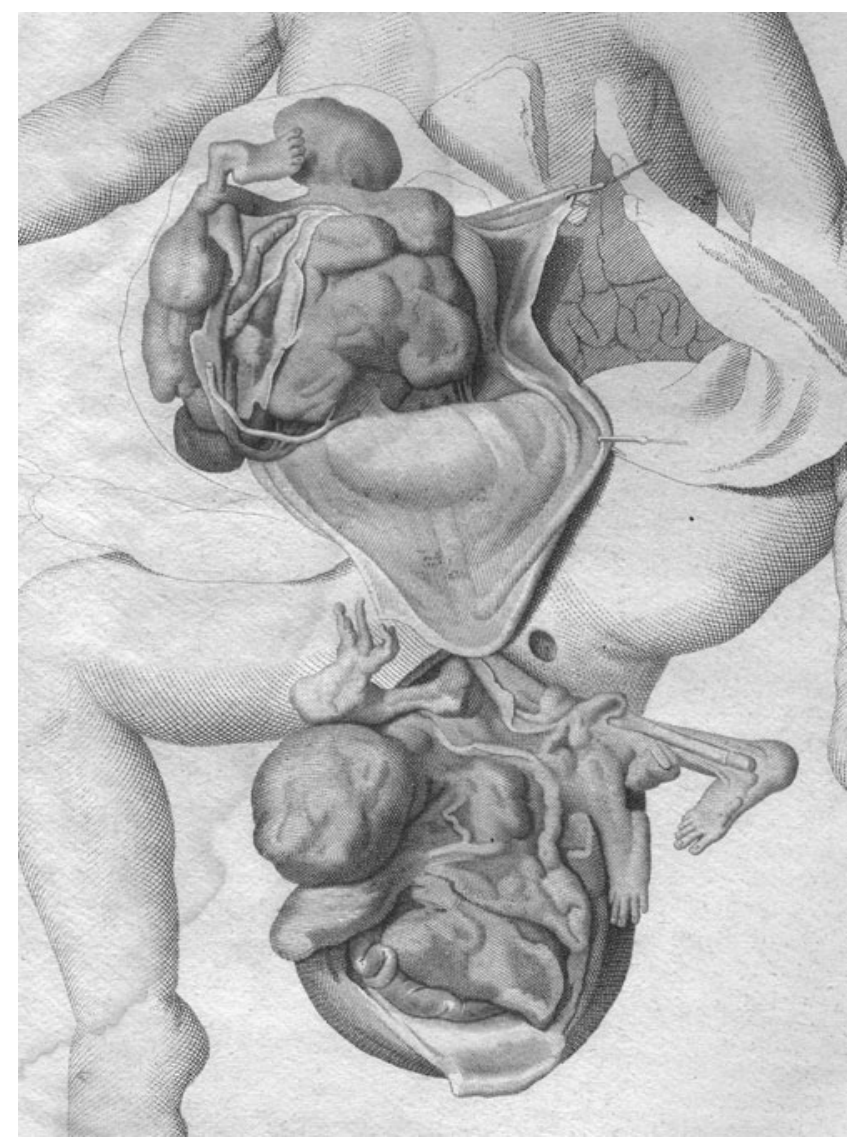

Fig. 8 Twin foeti in foetu, described and depicted in the 1815 folio monograph of Fattori [35]. Portion of figure on plate 1. This female fetus, delivered at 7 months gestation, contained two fetal inclusions, one in the abdomen and another in the pelvic cavity. Feet and other fetal structures are clearly identifiable in each mass 
particular interest to surgeons [40]. Its 34 copperplates of elephant folio size feature 574 finely stipple-engraved and outline figures depicting a wide array of malformations, mostly chosen from the previous literature. Figures were selected for their potential surgical interest and are organized in useful fashion. Facial clefts, urogenital anomalies, anorectal atresias, parasitic twins, and limb duplications are among the abnormalities depicted and discussed in this impressive work.

One of the most valuable resources for descriptive human teratology is the text and atlas of August Förster (18221865) [41]. This deceptively slender volume provides authoritative coverage of all major malformations, both external and visceral. It features succinct descriptions and simple but instructive line drawings by the author, a pathologist who was also a trained artist. Its 26 plates depict the essential features of hundreds of instructive cases from the literature and the author's experience. Its excellent critical bibliography, the first of its kind, has been the basis for most subsequent bibliographies of teratology.

Adolph Wilhelm Otto (1786-1845), one of the first pathologists with a particular interest in malformations, published a magnificent folio volume describing 600 specimens in the anatomical museum in Breslau [42]. This large folio volume is one of the great treasures in the history of the field. Its 30 copperplates, one partially colored, feature 146 figures depicting a variety of human malformations. Its 129 pages of Latin text provide detailed descriptions of each specimen, especially valuable because they include details concerning internal anatomy revealed by complete dissection of most specimens. Much rewarding work remains to be done on this work, which describes malformation complexes "discovered" in recent years and likely contains descriptions of syndromes yet to be recognized. This as well as Ottos' other significant contributions to teratology were the topic of an excellent study by Kampf [43].

An invaluable source of information on conjoined twins was a series of four lengthy articles by George Jackson Fisher (1825-1893) [44], accompanied by 30 engraved plates containing a total of 126 figures from the preceding literature. The fourth article included five plates depicting thoracopagic variants that were to be discussed in a fifth and final paper that was never published. This work includes detailed descriptions and fine illustrations from original sources that are now difficult if not impossible to find.

Cesare Taruffi (1821-1902), the first professor of pathology at the University of Bologna, published a series of eight volumes on the history of teratology from 1881 to 1894 [45]. Taruffi intended to continue this work with volumes on internal malformations, but these were never published. However, it remains by far the most extensive and detailed source of information on the history of teratology from the Renaissance to the latter decades of the nineteenth century. Taruffi mentions virtually every work previously published in this field. The first four volumes are most useful, covering the general history of teratology and the vast literature on conjoined twins. Despite its unique value, this work presents frustrating challenges. With the exception of occasional
Fig. 9 Epignathus parasitic twins in a female fetus of 5 months, reported in a rare monograph by Baart de la Faille [36]. Original not available; figure from Schatz [21], who suggested this was a case of parasitic triplets, of which the pharyngeal component represent the third parasite. Later restudy of the original specimen by Marchand [31] suggested that the pharyngeal mass represented rostral portions of twins whose caudal portions are obvious

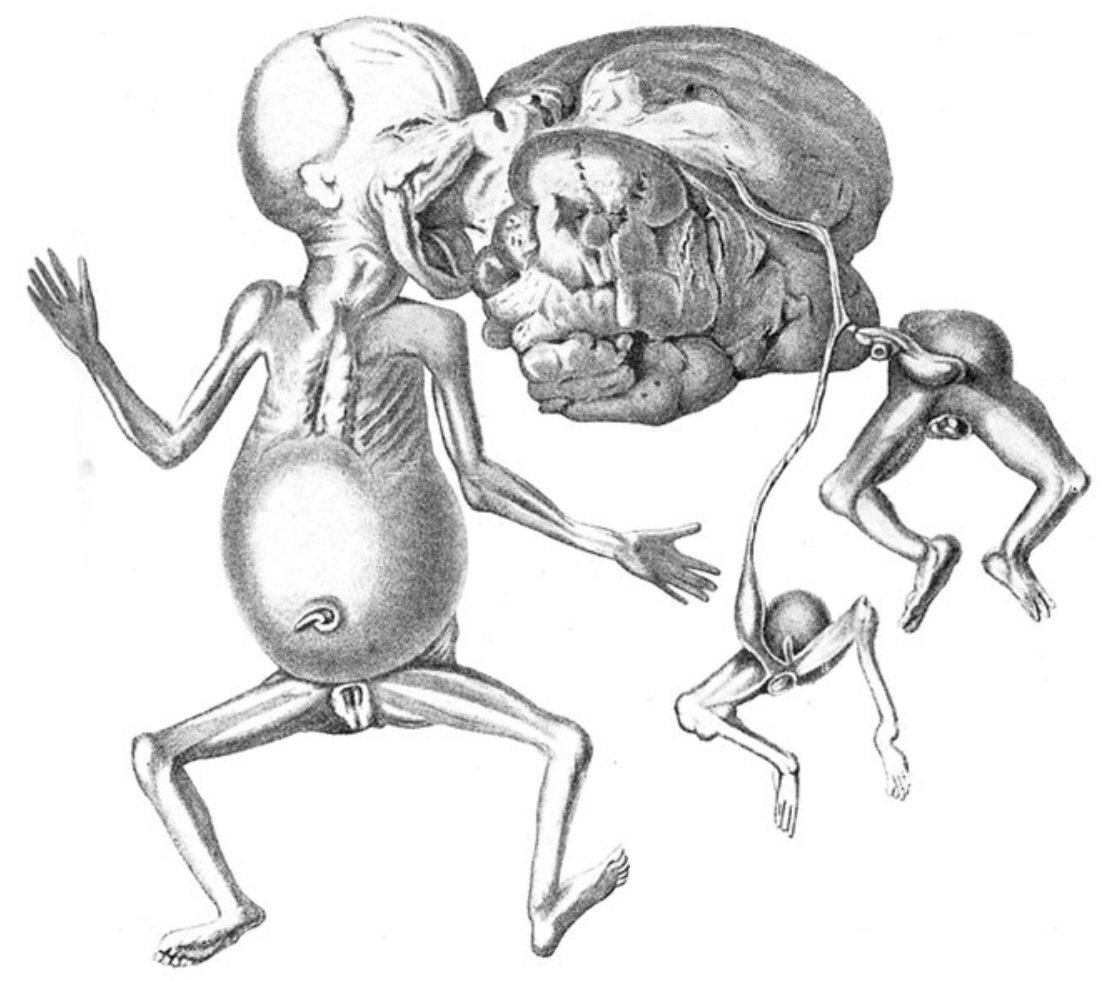


small line drawings, it has no illustrations. More importantly, it contains numerous typographical errors. The author's writing style is sometimes difficult to follow, even for native speakers of Italian. Despite these shortcomings, Taruffi's magnum opus contains vast amounts of information that is available nowhere else. This is the work I usually consult first when researching a topic in antiquarian teratology. A particularly useful feature is the inclusion of hundreds of tables summarizing details of cases reported by previous authors. Volume 4 contains a collective subject and author index to the first four volumes, while the remaining volumes contain only subject indexes for that volume.

A notable work that provides authoritative coverage of literature of the entire nineteenth century is the Manual of Antenatal Pathology and Hygiene: The Embryo [46], published in 1904 by John William Ballantyne (1861-1923). Ballantyne, an obstetrician with a profound interest in pathology, carried out postmortem examinations of numerous deformed fetuses and infants. A meticulous scholar, he was familiar with the literature of teratology in all the major languages of Europe. Some chapters in this work remain today the best discussions of specific malformations ever published. This book is a delight to read and is embellished by excellent photographs and drawings of personally studied cases.

Experimental teratology has its roots in this century. The studies of Camille Dareste (1822-1899) are the most influential pioneer in this field and are described by Fischer [47].The second edition of Dareste's summary work [48] provides an authoritative overview of this field up to the end of the nineteenth century.

\section{Twentieth century and the dawn of the molecular age}

The first half of this century witnessed significant expansion of knowledge in descriptive and experimental teratology. A notable contribution covering much of this period was the encyclopedic treatise on the morphology of malformations begun by Ernst Schwalbe (1871-1920) [49] and continued after Schwalbe's death under the editorship of Georg B. Gruber (1884-1960). The first two parts, written entirely by Schwalbe, were published in 1906 and 1907, respectively. Part 1 is devoted to historical and general considerations, while part 2 is a particularly valuable review of the complex topic of conjoined twinning. Part 3 is organized into three sections dealing with malformation types, organ systems, and body regions, issued in nineteen fascicles published from 1909 to 1958 , and index fascicle for part 3 was published in 1960, completing this monumental work. Despite its complex organization, this treatise of 3,885 pages, with more than 2,000 illustrations, is an indispensable resource for information on both descriptive and experimental teratology of humans and other vertebrates in the first half of the twentieth century. By mid-century, major progress had been made in experimental embryology, epidemiology, teratogenetic mechanisms, cytogenetic studies, and characterization of dysmorphic syndromes. A general overview of this era is included in Gruber's separate historical study [50].

The elucidation of the structure of DNA in 1953 inaugurated the age of molecular biology, in which the mechanisms of abnormal development are explored at fundamental levels previously viewed as unattainable. New discoveries and concepts are revealed at a pace that exceeds the capacity of the printing press. Concepts are often developed, expanded, and superseded almost overnight, and an adequate history of this period can only be written by a future generation.

In the present era, when it is difficult if not impossible to keep abreast of new knowledge in most fields of science, the writings of past generations might seem of value only to historians. But the literature of teratology created by past generations is a resource of permanent value to medicine and science. Works from the golden age of gross anatomy and pathology contain superb depictions and descriptions of rare anomalies that are an invaluable source of gross anatomical information. In addition, the older literature includes descriptions of numerous unique specimens that reveal key information concerning specific malformation patterns. The older literature is also essential for determining whether a particular abnormality is new or changing in incidence. Descriptions of the lives of persons born with various malformations prior to the development of effective surgical amelioration can be helpful in making management decisions such as surgical separation of certain patterns of conjoined twinning. It is hoped that the present review will prove helpful to those wishing to explore this valuable and fascinating resource.

\section{References}

1. Dasen V (1993) Dwarfs in ancient Egypt and Greece. Clarendon, Oxford

2. Jastrow M Jr (1914) Babylonian-Assyrian birth-omens and their cultural significance. Religionsgeschichtliche Versuche und Vorarbeiten, Bd. 15, Heft 5:[i]-vi, 1-86

3. Céard J (1977) La nature et les prodiges. L'insolite au XVI ${ }^{\mathrm{e}}$ siècle, en France. Librairie Droz, Geneva, A second edition was issued in 1996, with insignificant additions and in much smaller format than the original

4. Lycosthenes K (1557) Prodigiorum ac ostentorum chronicon. Henricum Petri, Basel, A German edition published the same year, entitled "Wunderwerck oder Gottes unergründtliches Vorbilden", is available in a facsimile edition published by Georg Olm in 2007 
5. Paré A (1573) Deux livres de chirurgie. I. De la generation de l'homme. II. Des monstres tant terrestres que marins avec leurs portraits. André Wechel, Paris

6. Céard J (1971) Ambroise Paré. Des monstres et prodigies, Édition critique et commentée. Librairie Droz, Geneva

7. Pallister JL (1982) Ambroise Paré. On monsters and marvels. Translated with an introduction and notes. University of Chicago Press, Chicago

8. Rueff J (1554) De conceptu et generatione hominis. Christoph Froschouer, Zürich, German edition issued the same year. Reprint edition illustrated by Jost Ammann published in Frankfurt in 1580 and 1587. Modern reprint of the 1587 edition published in 1980 by Medicina Rara. An English translation, first published in 1637 and available in modern reprint, omits most of the section dealing with monsters

9. Aldrovandi U (1642) Monstrorum Historia. Nicolai Tebaldini, Bologna, A reprint edition, in a somewhat smaller format than the original folio volume, was published in 2002 by Nino Aragno Editore

10. Liceti F (1634) De Monstrorum Caussis, Natura, et Differentiis, Libri Duo, 2nd edn. Paulum Frambottum, Padua, The first edition was published in 1616 without illustrations. An excellent third edition, with an appendix by Gerard Blasius, was published in 1665 by Andreae Frisii, Amsterdam. A French translation of the 1665 edition, with excellent reproduction of the plates, was included in Jean Palfyn's Description Anatomique des Parties de la Femme, qui Servent à la Generation, published in Leyden in 1708. An abbreviated reprint of portions of Liceti's text in French, with comments by Francois Houssay, was published by Editions Hippocratique in 1937

11. Schenck JG (1609) Monstrorum historia memorabilis. Matthiae Becker, Frankfurt

12. Benivieni A (1507) De abditis nonnullis ac mirandis morborum et sanitationum causis. Translation by Charles Singer, with biographical appreciation by Esmond L. Long. Charles C, Thomas, Springfield, 1954

13. Chavarria AP (1924) The Siamese twins of Española. The first known post-mortem examination in the New World. Ann Med Hist 6:297-302

14. Harvey W (1651) De generatione animalium. Typis du-Gardianis; impensis Octaviani Pulleyn in Coemeterio Paulino, London

15. Roe SA (1981) Matter, life and generation. Eighteenth-century embryology and the Haller-Wolff debate. Cambridge University Press, Cambridge

16. Tort P (1980) L'ordre et les monstres. Le débat sur l'origine des deviations anatomiques au XVIIIe siècle. Le Sycamore, Paris

17. Sömmerring ST (1791) Abbildungen und Beschreibungen einiger Misgeburten die sich ehemals auf dem anatomischen Theater zu Kassel befanden. Universitätsbehandlung, Mainz, Enke's important study of this work, including a reprint of the original, was published in 2000 by Schwabe \& Co., Basel

18. von Haller A (1768) Operum anatomici argumenti minorum, Tomus tertius. Francisci Grasset, Lausanne

19. Clark O (1969) The contribution of J. F. Meckel, the Younger, to the science of teratology. J Hist Med 24:310-322

20. Meader RG (1937) The Meckel dynasty in medical education. Yale J Biol Med 10:1-29

21. Schatz F (1900) Die Gefässverbindungen der Placentakreisläufe eineiiger Zwillinge, ihre Entwicklung und ihre Folgen. Arch Gynäkol 60:Tafel V

22. Marchand F (1912) Über den Epignathus (Fall II) von Baart de la Faille. Arch Entwicklugsmechanik Organ 35:189-209

23. Beneke R (1934) Johann Fredrich Meckel der Jüngere. Beitr. z. Gesch. d. Universität Halle-Wittenberg, Band 3

24. Meckel JF (1809) Ueber die Divertikel am Darmkanal. Archiv Physiol 9:421-453
25. Meckel JF (1812-1818) Handbuch der pathologischen Anatomie. Carl Heinrich Reclam, Leipzig

26. Schierhorn H (1984) Johann Friedrich Meckel d. J. als Begründer der wissenschaftlichen Teratologie. Gegenbaurs Morphol Jahrb 130:399-439

27. Meckel JF (1815) De duplicitate monstrosa commentarius. Halle and Berlin, Librariis Orphanotrophei. 96 p., 8 plates

28. Meckel JF (1817-26) Tabulae anatomico-pathologicae. Leipzig. IF Gleditsch

29. Klunker UR (2003) Bestand und Identität der human-teratologischen Präparate in den Meckel'schen Sammlungen under besonderer Berücksichtigung des wissenschaftlichen Werkes von Johann Friedrich Meckel dem Jüngeren (1781-1833). Diss. Med. Fak. Der Martin-Luther-Universität Halle-Wittenberg. Available online at http://sundoc.bibliothek.uni-halle.de/diss-online/03/03H116/ prom.pdf

30. Geoffroy St.-Hilaire I (1832-1837) Histoire des anomalies de l'organisation chez l'homme et les animaux. J-B Baillière, Paris. 3 volumes plus atlas of 20 plates

31. Le Guyader H (2004) Geoffroy Saint-Hilaire: a visionary naturalist. University of Chicago Press, Chicago

32. Geoffroy St.-Hilaire É (1822) Philosophie anatomique. Des Monstruosités Humaines. Paris, Chez 1,auteur

33. Gurlt EF (1832) Lehrbuch der pathologischen Anatomie der HausSäugethiere, Zweiter Teil, welcher die Classification, Beschreibung und Anatomie der Missgeburten enthält. Mit Atlas. G. Reimer, Berlin

34. Gurlt EF (1877) Ueber thierische Missgeburten. Ein Beitrag zur pathologischen Anatomie und Entwickelungs-Geschichte. August Hirschwald, Berlin

35. Fattori S (1815) De feti che racchiudono feti. Tipografia Giovanni Capelli, Pavia

36. Baart de la Faille J (1874) Jets over den Epignathus. Groningen. (Rare monograph, not available to the present author. Depicted by Schatz Arch. Gynaekol. 60: Taf. V, 1900)

37. Vrolik W (1849) Tabulae ad illustrandam embryogenesin hominis et mammalium tam naturalem quam abnormem. GMP Londonck, Amsterdam, A German edition, issued by T.O. Weigel of Leipzig in 1854, consists of unsold sets of the Amsterdam edition, with a new title page. An English translation, published by Greenwood Genetics Center in 2004, makes the text more accessible to modern readers, with suboptimal reproduction of the plates

38. Vrolik W (1840-1842) Handboek der ziektekundige ontleedkunde. Eerste deel, Tweede deel, Aangeborene gebreken. Johannes Müller, Amsterdam

39. Ahlfeld F $(1880,1882)$ Die Missbildungen des Menschen. Fr. Wilh. Grunow, Leipzig. Abschnitt 1 (1880). Text pages 1-144, Atlas plates 1-23. Abschnitt 2 (1882) Text pages 145-297, Atlas plates $24-49$

40. von Ammon FA (1842) Die angeborenen chirurgischen Krankheiten des Menschen in Abbildungen dargestellt. F.A. Herbig, Berllin

41. Förster A (1861) Die Missbildungen des Menschen systematisch dargestellt. Friedrich Mauke, Jena. Text and Atlas with 26 lithographed plates containing 524 figures. A second edition, issued posthumously in 1865 , contains identical text and figures

42. Otto AW (1841) Monstrorum sexcentorum descriptio anatomica. Ferdinand Hirt, Breslau

43. Kampf K (1987) Teratologie als Vorstufe einer Entwicklungsgeschichte. A.W. Otto (1786-1845) und sein "Museum Monstrorum" Breslau 1841. Band 47 in Arbeiten der Forschungsstelle des Instituts für Geschichte der Medizin der Universität zu Köln. p 243

44. Fisher GJ (1865-8) Diploteratology, an essay on compound human monsters. Trans Med Soc State N Y 1865, 232-268; 1866, 207$296 ; 1867,396-430 ; 1868,276-306$ 
45. Taruffi C (1881-1894) Storia della teratologia, Tomo I-VIII. Regia Tipografica, Bologna

46. Ballantyne JW (1904) Manual of antenatal pathology and hygiene. The Embryo. William Green and Sons, Edinburgh, The American edition published by William Wood and Sons in 1905 is identical to the Edinburgh one except for the title page. An excellent facsimile reprint was published by Greenwood Genetics Center in 1991

47. Fischer J-L (1994) Leben und Werk von Camille Dareste (18221899), Schöpfer der experimentellen Teratologie. Acta Historica
Leopoldina, No. 21, Deutsche Akademie der Naturforscher Leopoldina, Halle/Salle

48. Dareste C (1891) Recherches sur la producton artificielle des Monstruosités, ou Essais de tératogénie expérimentale. Paris, C. Reinwald

49. Schwalbe E, Gruber GB (eds) (1906-60) Morphologie der Missbildungen des Menschen und der Tiere. Gustav Fischer, Jena 50. Gruber GB (1963-4) Studien zur Historik der Teratologie. Zentralblatt f. allgemeine Pathologie u. Pathol Anat 105:293-316 and 106:512-562 